\title{
Microstructure and Thermal Conductivity of Fully Ceramic Microencapsulated Fuel Fabricated by Spark Plasma Sintering \\ DOI:
}

10.1111/jace. 15585

\section{Document Version}

Accepted author manuscript

Link to publication record in Manchester Research Explorer

Citation for published version (APA):

Cao, F., Fan, X., Liu, B., Zhao, X., Guo, F., \& Xiao, P. (2018). Microstructure and Thermal Conductivity of Fully Ceramic Microencapsulated Fuel Fabricated by Spark Plasma Sintering. Journal of the American Ceramic Society. https://doi.org/10.1111/jace.15585

\section{Published in:}

Journal of the American Ceramic Society

\section{Citing this paper}

Please note that where the full-text provided on Manchester Research Explorer is the Author Accepted Manuscript or Proof version this may differ from the final Published version. If citing, it is advised that you check and use the publisher's definitive version.

\section{General rights}

Copyright and moral rights for the publications made accessible in the Research Explorer are retained by the authors and/or other copyright owners and it is a condition of accessing publications that users recognise and abide by the legal requirements associated with these rights.

\section{Takedown policy}

If you believe that this document breaches copyright please refer to the University of Manchester's Takedown Procedures [http://man.ac.uk/04Y6Bo] or contact uml.scholarlycommunications@manchester.ac.uk providing relevant details, so we can investigate your claim.

\section{OPEN ACCESS}


PROFESSOR XIAOFENG ZHAO (Orcid ID : 0000-0001-8390-4301)

DR FANGWEI GUO (Orcid ID : 0000-0002-4996-9846)

Article type : Article

Microstructure and Thermal Conductivity of Fully Ceramic Microencapsulated Fuel

\section{Fabricated by Spark Plasma Sintering}

Fangcheng Cao ${ }^{1}$, Xiaohui Fan ${ }^{1}$, Bing Liu ${ }^{2}$, Xiaofeng Zhao ${ }^{1, *}$, Fangwei Guo ${ }^{1}$ and Ping Xiao 3,1

${ }^{1}$ School of Materials Science and Engineering, Shanghai Jiao Tong University, Shanghai

200240, China

${ }^{2}$ Institute of Nuclear and New Energy Technology, Tsinghua University, Beijing 100048,

China

*Corresponding author: Xiaofeng Zhao (xiaofengzhao@sjtu.edu.cn)

This article has been accepted for publication and undergone full peer review but has not been through the copyediting, typesetting, pagination and proofreading process, which may lead to differences between this version and the Version of Record. Please cite this article as doi: $10.1111 /$ jace. 15585

This article is protected by copyright. All rights reserved. 
${ }^{3}$ School of Materials, University of Manchester, Manchester M13 9PL, United Kingdom

\section{Abstract}

Fully ceramic microencapsulated pellet (FCM), consisting of tristructural isotropic (TRISO)

particles embedded in silicon carbide ( $\mathrm{SiC}$ ) matrix, was fabricated using spark plasma sintering. The parameters affecting the densification of $\mathrm{SiC}$ matrix were first investigated, and then FCM pellets were prepared using TRISO particles with/without outer pyrolytic carbon (OPyC) layer. Effects of thermal exposure on the TRISO particles during SPS were evaluated. In addition, the thermal condcutvitities of FCM pellet, as well as the SiC matrix, were measured using laser flash. It was revealed that the TRISO particles with OPyC layers significantly lower the thermal conductivity of FCM pellet. Based on Maxwell-Eucken model, the predicted effective thermal conductivities of TRISO particles with/without OPyC layers were $14.4 \mathrm{~W} / \mathrm{mK}$ and $25.2 \mathrm{~W} / \mathrm{mK}$, respectively. Finite elements simulation indicated that the SiC layer in TRISO particle plays a dominant role on the thermal conductivity of This article is protected by copyright. All rights reserved. 
FCM. The presence of OPyC layers would generate gaps/porous SiC near the interface and

resist the heat flows, leading to a lower thermal conductivity of FCM.

Keywords: Fully ceramic microencapsulated pellet; Spark plasma sintering; SiC; TRISO;

Thermal conductivity.

\section{Introduction}

Tristructural isotropic (TRISO) fuel particle consists of a spherical fuel kernel and four successive coated layers, namely porous carbon layer (buffer), dense inner pyrolytic carbon layer (IPyC), silicon carbide layer ( $\mathrm{SiC})$ and outer pyrolytic carbon layer (OPyC) from inner to outside. These layers serve as a pressure vessel to contain fission products and maintain structural integrity of TRISO particle ${ }^{1}$. TRISO particle system has been designed and optimized for high-temperature gas-cooled reactors (HTGRs). In conventional HTGRs applications, the TRISO particles are dispersed in a graphite matrix, producing compacts in form of pebbles or prismatic block ${ }^{2}$. However, the graphite matrix undergoes significant physical property changes, especially, suffers anisotropic dimensional instability, due to This article is protected by copyright. All rights reserved. 
irradiation, which results in a short lifetime ${ }^{3}$. Recently, fully ceramic microencapsulated (FCM) fuel that consists of TRISO particles embedded in SiC matrix has attracted tremendous interest ${ }^{4-9}$. The FCM fuel enable TRISO particles to apply in other reactor systems such as fluoride-salt cooled and water cooled reactors ${ }^{6-8}$. Furthermore, the FCM fuel could offer the following potential advantages: high thermal conductivity of $\mathrm{SiC}$ matrix ${ }^{4,6}$, additional barriers to retain fission product ${ }^{10}$, excellent resistance to neutron exposure ${ }^{3}$, environmental stability and strength retention under high temperature operating conditions ${ }^{7}$. Therefore, it is expected that the FCM fuel can not only realize higher fuel burnup and power conversion efficiency of the fuel coupled with the small temperature gradient across the fuel, but also alleviate the thermal stress and enhance the accident tolerance ${ }^{11}$.

Generally, FCM fuel is compacted in form of pellets or pebbles, where the SiC matrix is densified with uniformly distributed TRISO particles of a certain volume fraction $5,8,9$. Preparation of the FCM fuel has been previously performed using hot pressing sintering with a duration of an hour or more ${ }^{5,8}$. It is assumed that the TRISO particles will not be damaged during the FCM compaction processes. The densification of FCM pellets should be achieved with limited amount of oxide additives to aviod the drawbacks of oxide phases under This article is protected by copyright. All rights reserved. 
irradiation (i.e., neutron absorption or swelling) ${ }^{8,12}$. Besides, lowering the fabrication temperature is of great importance to slow the grain growth in the SiC layers of the TRISO particles, which would result in unacceptable deterioration in mechanical property ${ }^{5,8}$. It is also worth mentioning that the thermal treatment from the high fabrication temperature affects the TRISO particle, especially on the disorder and mechanical degradation in the PyC layers ${ }^{13,14}$. Compared with the conventional sintering methods, the spark plasma sintering (SPS) method can achieve high densification at noticeable lower temperature and shorter time, thus minimizing the thermal treatment effects ${ }^{15} . \mathrm{SiC}$ is a complex material whose properties vary greatly dependent on the fabrication route ${ }^{16}$. Hence, a fundamental understanding of the matrix materials and SPS processing conditions is necessary to achieve the ideal properties. In FCM compact, the SiC matrix replaces the graphite matrix and becomes the most important safety feature that protects the TRISO particles from damage of mechanical effects such as abrasion. Thus the machanical property of SiC matrix should be studied. Meanwhile, the SiC matrix not only stabilizes the TRISO particles in the FCM pellets but also functions as a good heat transfer medium ${ }^{17}$. Therefore, the thermal conductivites of both the $\mathrm{SiC}$ matrix and the TRISO particle are worth to be investigated.

This article is protected by copyright. All rights reserved. 
In this study, the SiC matrix and FCM pellet were fabricated using SPS technique. The influences of various sintering conditions on the microstructure of $\mathrm{SiC}$ matrix were invesitgated. The thermal effects during the SPS process on the microstructure of the PyC layers in TRISO particles were discussed. The hardness and Young's modulus of SiC matrix was determined using micro-indentation. The thermal conductivities of SiC matrix and FCM pellet with TRISO particles with/without OPyC layers were evaluated using laser flash technique. The effective thermal conductivity of TRISO particle was also predicted using the Maxwell-Eucken model ${ }^{18}$. In addition, the presence of the OPyC layers on the thermal conductivity of FCM pellet was discussed.

\section{Experimental procedure}

\subsection{Material Preparation}

The starting powder was fine $\beta-\mathrm{SiC}$ with an average particle size of $\sim 40 \mathrm{~nm}$ (99.9\%, Aladdin

Chemical Co., Ltd., China). A mixture oxides powder of $\mathrm{Al}_{2} \mathrm{O}_{3}$ and $\mathrm{Y}_{2} \mathrm{O}_{3}$ with an average particle size of $\sim 30 \mathrm{~nm}(99.99 \%$, Aladdin Chemical Co., Ltd., China) were added in the ratio corresponding to the yttrium aluminum garnet (YAG) stoichiometry $\left(\mathrm{Al}_{2} \mathrm{O}_{3}: \mathrm{Y}_{2} \mathrm{O}_{3}=5: 3\right.$ in 
molar ratio) as sintering additives. The amount of oxide additives was at a range of $2 \mathrm{wt} \%-10$

wt $\%$. The powder mixture was mixed by ball milling using $\mathrm{SiC}$ media in a polypropylene jar

for $24 \mathrm{~h}$ in isopropyl alcohol. The mixture was dried, crushed, and then screened through a

60-mesh sieve. The simulated TRISO particle samples were made by fluidized bed chemical

vapor deposition using zirconia particles with a diameter of $\sim 510 \mu \mathrm{m}$ as kernels instead of fuel. The average thickness of the buffer, IPyC, SiC, and OPyC layers were about 95, 40, 35 and $40 \mu \mathrm{m}$, respectively. Some TRISO particles were exposed in air at $800{ }^{\circ} \mathrm{C}$ for 8 hours to oxidize the OPyC layers.

\subsection{SPS fabrication}

Prior to high-temperature consolidation, the powder feedstock was cold pressed inside a steel

die. Monolithic green bodies prepared via biaxial cold pressing at $\sim 5 \mathrm{MPa}$ exhibited green density about $30 \%$ of theoretical SiC density. Subsequently, the green bodies were individually spark plasma sintered (KCE-FCT-HP D 25/4-SD, FCT Systeme GmbH, Germany) using graphite dies at $1850^{\circ} \mathrm{C}$ under a uniaxial pressure of $10-20 \mathrm{MPa}$ for $10-20$ min. The load was released and the electrical power was shut down by the end of the 
dwelling time to allow rapid cooling to room temperature. The various SPS conditions for the fabrication of SiC matrix (S1-S6) were listed in Table 1.

\subsection{Characterization}

The morphology and chemical composition of the starting SiC powder was observed using transmission electron microscope (TEM) (TALOS F200X, FEI, USA) and X-ray photoelectron spectroscopy (XPS) (AXIS Ultra DLD, Kratos, Japan), respectively. Focused ion beam (FIB) (GAIA3, Tescan, Czech Republic) combined with SEM was used for sample preparation for the HREM observations. The bulk density $(\rho)$ of the specimen after consolidation was determined using the Archimedes' method, with water as the immersing medium. The relative density of sintered materials was calculated using the theoretical density of the $\mathrm{SiC}$ matrix. The oxide additives of $\mathrm{Al}_{2} \mathrm{O}_{3}$ and $\mathrm{Y}_{2} \mathrm{O}_{3}\left(\mathrm{Al}_{2} \mathrm{O}_{3}: \mathrm{Y}_{2} \mathrm{O}_{3}=5: 3\right.$ in molar ratio) would react to form the YAG compound during the sintering of SiC. So, the theoretical density of the $\mathrm{SiC}$ matrix could be estimated according to the ratio of mixture, using theoretical density for YAG and $\mathrm{SiC}$ of $4.54 \mathrm{~g} / \mathrm{cm}^{3}$ and $3.21 \mathrm{~g} / \mathrm{cm}^{3}$, respectively ${ }^{19}$. The microstructure of FCM pellet sample was examined using a scanning electron microscope (SEM) (Inspect F50, FEI, USA). The phase analysis of the SiC matrix and TRISO particle This article is protected by copyright. All rights reserved. 
was determined by means of X-ray diffractometer (XRD) (Ultima IV, Rigaku, Japan) and

Raman spectroscopy (LabRAM HR Evolution, HORIBA Jobin Yvon, France). The measurement of hardness and Young's modulus were performed on the finely polished SiC by micro-indentation technique (MHT, Anton Paar, Austria), using a Vickers indenter at a maximum load of $2 \mathrm{~N}$. Arrays of indentations were performed on each specimen with an interval of $100 \mu \mathrm{m}$, which is much more than 20 times the indentation depth of $\sim 2.5 \mu \mathrm{m}$. Thermal conductivity $(k)$ was measured at room temperature using laser-flash technique. A plate sample $(10 \mathrm{~mm} \times 10 \mathrm{~mm} \times 3 \mathrm{~mm})$ was prepared for the thermal diffusivity $(\alpha)$ measurement using the Laser Flash Analyzer (LFA447, Netzsch, Germany). The specific heat capacity $\left(c_{p}\right)$ was measured using the differential scanning calorimeter (DSC 8000, Perkin Elmer, America) with a disk sample $(\sim 5 \mathrm{~mm}$ diameter $\times 1.5 \mathrm{~mm}$ thickness $)$. Then the thermal conductivity $(k)$ can be determined using the relation: $k=\alpha \cdot \rho \cdot c_{p}$.

\section{Results and discussion}

Figure 1 is a representative TEM image of the starting SiC powder. The variation in powder size appeared to be broad with a range of $40 \mathrm{~nm}$ to $150 \mathrm{~nm}$. It was found that the surface of $\mathrm{SiC}$ nanopowder was covered by a layer of amorphous silicon oxide with a thickness of $\sim 1$ This article is protected by copyright. All rights reserved. 
nm. Detailed chemical characterization for impurity phase was performed using XPS by chemical bond analysis. Figure 2 shows the spectra for $\mathrm{O}_{1 \mathrm{~s}}\left(\mathrm{E}_{\mathrm{b}}=\sim 538 \mathrm{eV}\right), \mathrm{C}_{1 \mathrm{~s}}\left(\mathrm{E}_{\mathrm{b}}=\sim 291\right.$ $\mathrm{eV}), \mathrm{Si}_{2 \mathrm{P}}\left(\mathrm{E}_{\mathrm{b}}=\sim 106 \mathrm{eV}\right)$ and $\mathrm{Si}_{2 \mathrm{~s}}\left(\mathrm{E}_{\mathrm{b}}=\sim 153 \mathrm{eV}\right)$ signals ${ }^{20}$ of both $\mathrm{SiC}$ powder and the $\mathrm{SiC}$ matrix sample fabricated using SPS. The presence of $\mathrm{O}_{1 \mathrm{~s}}$ peak implies that the oxygen element, which existed on the surface of $\mathrm{SiC}$ nanopowder (Figure 1), was in the form of $\mathrm{SiO}_{2}$ or $\mathrm{SiO}_{x} \mathrm{C}_{y}{ }^{8,21}$. The ratio of the intensity of $\mathrm{O}_{1 \mathrm{~s}}$ to $\mathrm{Si}_{2 \mathrm{P}}$ of the starting $\mathrm{SiC}$ power (2.1) was close to that of the pure SiC matrix sample (2.0) fabricated using SPS without oxide additives, which indicates the oxidation of $\mathrm{SiC}$ matrix during SPS precedure can be neglected.

\subsection{The phase, microstructure and mechanical property of the $\mathrm{SiC}$ matrix}

Figure 3 presents the XRD patterns of the starting $\mathrm{SiC}$ powder, the mixed SiC powder with 5wt\% oxide additives and SPS SiC matrix, respectively. The XRD spectra of the starting SiC powder correspond to stoichiometry $\beta-\mathrm{SiC}$, showing the extra peak at $2 \theta \sim 33.5^{\circ}$ and a broadening peak at $2 \theta \sim 35.3^{\circ}$, which could be attributed to the existence of a high density of stacking faults in the regular cubic sequences ${ }^{22}$. In the mixed SiC powder, it revealed that $\beta$-SiC presented as a major phase with a minor amount of $\mathrm{Y}_{2} \mathrm{O}_{3}$ except for $\mathrm{Al}_{2} \mathrm{O}_{3}$, suggesting This article is protected by copyright. All rights reserved. 
the concentration of $\mathrm{Al}_{2} \mathrm{O}_{3}(2 \mathrm{wt} . \%)$ was below the detectability limit of XRD ${ }^{23}$. In this study, the low amount of oxide additives was designed to acquire high radiation resistant of $\mathrm{SiC}$ matrix. For the SPS SiC matrix sample, the XRD pattern only presents $\mathrm{SiC}$ polycrystalline structure. It indicates the annihilation of the stacking faults in starting $\mathrm{SiC}$ powder ${ }^{14}$, and the oxide additives precipitated as glass phases in SiC matrix after SPS $\operatorname{processing}^{24}$.

Figure 4 shows the microstructure of SiC matrix (S1-S6) using SPS at $1850{ }^{\circ} \mathrm{C}$, where $\mathrm{SiC}$ appeared as a gray phase, while the black spots and bright areas corresponded to pores and oxide phases at the $\mathrm{SiC}$ grain boundaries, respectively. The $\mathrm{SiC}$ grains exhibited equiaxed shape with sizes from $0.5 \mu \mathrm{m}$ to $1.5 \mu \mathrm{m}$, meaning that the grains have grown nearly ten-times larger compared with the starting powder (Figure 1). Figures $4 \mathrm{~A}-4 \mathrm{C}$ represent the SiC matrix (S1-S3) sintered under $10 \mathrm{MPa}, 15 \mathrm{MPa}$ and $20 \mathrm{MPa}$, respectively, with oxide additives of $5 \mathrm{wt} \%$ and dwelling time of $10 \mathrm{~min}$. The sample sintered under $10 \mathrm{MPa}$ of pressure (S1) contained a large amount of pores, while higher sintering pressure (15 MPa for S2 and $20 \mathrm{MPa}$ for S3) produced an enhanced densification. The lower sintering pressure (15 MPa) was preferred to prevent TRISO particles from being damaged during the FCM This article is protected by copyright. All rights reserved. 
compaction process. The addition of oxide additives with different content ( $2 \mathrm{wt} . \%$ for S4

and 10 wt.\% for S5) had significant effects on the microstructure of the SiC matrix, as shown

in Figures 4B, 4D and 4E. The SiC matrix with 2 wt.\% oxide additives (S4) showed a poor sinterability with a lot of pores. With addition of $10 \mathrm{wt} . \%$ oxide additives (S5), a fully dense $\mathrm{SiC}$ matrix could be achieved. It was also observed that the sample S5 had much smaller and homogenous grain size distribution, indicating the oxide additives aggregated at grain boundaries inhibited the grain growth. Compared with sample S2, no apparent changes were observed in sample S6 with a longer dwelling time of $20 \mathrm{~min}$ (Figure 4F), which indicates the dendification procedure could not be facilitated using a prolonged time period at $1850{ }^{\circ} \mathrm{C}$.

At the given temperature $\left(1850{ }^{\circ} \mathrm{C}\right)$, the influences of the SPS sintering conditions on the density and mechanical property of $\mathrm{SiC}$ matrix were analyzed, as shown in Table 2 . The $\mathrm{SiC}$ matrix sintered at $1850{ }^{\circ} \mathrm{C}$ with $5 \mathrm{wt} . \%$ oxide additives for $10 \mathrm{~min}$ (S2) yielded a density of $2.97 \mathrm{~g} / \mathrm{cm}^{3}$ (91\% relative density). Relative density increased with an increase of the amount of sintering additives from 2 wt.\% to $10 \mathrm{wt} \%$ (S4, S2 and S5). A 98\% relative density was obtained with $10 \mathrm{wt} \%$ oxide additives (S5). The density of the SiC matrix hardly changed with the dwelling time varied from $10 \mathrm{~min}$ to $20 \mathrm{~min}$ (S2 and S6), which indicates This article is protected by copyright. All rights reserved. 
SPS could achieve compaction process at a short dwelling time. Meanwhile, the hardness and

the Young's modulus of the sample S2 was $21.3 \mathrm{GPa}$ and $313 \mathrm{GPa}$ respectively, which fell into the range of hardness $(21.1-29.7 \mathrm{GPa})$ and Young's modulus (300-400 GPa) for sintered $\beta$-SiC ${ }^{1}$, implying the SPS is an effective method for the fabrication of SiC matrix. Both the hardness and the Young's modulus of the $\mathrm{SiC}$ matrix increased as a function of the relative density. Inversely, the SiC matrix of near full density (98\% relative density) sintered with 10 wt.\% oxide additives (S5) showed a slight decrease of the hardness and Young's modulus. It could attribute to a large amount of oxide additives in sample S5 that located at the grain boundaries (Figure 4E) as glass phases after sintering could lower the hardness and Young's modulus of the $\mathrm{SiC}$ matrix ${ }^{21}$.

Therefore, the presence of the oxide additives could realize high densification as well as deteriorate the hardness and Young's modulus of the SiC matrix. To achieve a high-density SiC matrix with low amount of oxide additives and intact TRISO particles embedded (i.e., FCM pellet), the SPS was performed at $1850{ }^{\circ} \mathrm{C}$ with $5 \mathrm{wt} . \%$ oxide for 10 min of dwelling time and $15 \mathrm{MPa}$ of pressure in this study, which had the same sintering condition as sample S2.

This article is protected by copyright. All rights reserved. 


\subsection{The microstructure of the FCM}

Figure 5A and 5B show the FCM pellet with TRISO particles ( 24 vol.\%) and the FCM

pellet with the same number of TRISO particles ( 20 vol.\%) with the OPyC layers removed

by oxidation in air, respectively. The TRISO particles appeared randomly dispersed, and

remained undamaged with no collision occurred during the matrix consolidation process. In

FCM fuel, this is an essential performance metric in order to act as the fuel particle pressure

vessel and prevent fission products from escaping ${ }^{10}$.

Figure 6A was taken in the vicinity of a TRISO particle with OPyC layer and shows the

presence of gap at the interface between the TRISO particle and the SiC matrix. Besides, a

porous $\mathrm{SiC}$ layer with a thickness of $\sim 15 \mu \mathrm{m}$ (Figure 6A2) was observed near the interface.

The original thickness of the OPyC layer was about $40 \mu \mathrm{m}$, while a thickness of $\sim 25 \mu \mathrm{m}$

(measrued from the cross section at hemishperical TRISO praticles) for the OPyC layer was

observed after SPS. That is, the OPyC layers presented a thickness reduction of $\sim 15 \mu \mathrm{m}$

apparently after SPS. Figure 6B presents the image of the TRISO without the OPyC layers in

FCM. The SiC layers in the TRISO particles remained intact after SPS process. As shown in

the higher magnification image, the interface between the TRISO particle and the SiC matrix This article is protected by copyright. All rights reserved. 
exhibited good contact without apparent voids or debonding. Furthermore, sintering at the interface of the $\mathrm{SiC}$ layer and the $\mathrm{SiC}$ matrix occurred without apparent interface (Figure 6B2), which would facilitate the heat transfer.

The visible gap observed at the inerface of the OPyC layer and the SiC matrix might be caused by the mismatch of thermal expansion coefficient. Because pyrolytic carbon has a larger thermal expansion coefficient of $6-8 \times 10^{-6} / \mathrm{K}^{25}$, which is almost twice larger than that of $\beta$-SiC $\left(3.2 \times 10^{-6} / \mathrm{K}^{26}\right)$, the OPyC layers would shrink more than the SiC matrix during the cooling. Both the presence and absence of pores in the SiC matrix near the OPyC layer was reported in different studies without scientific explanations, in which the FCM pellets were produced using hot pressing ${ }^{5,9}$. Therefore, the reactions between the $\mathrm{OPyC}$ and $\mathrm{SiC}$ can be ruled out. In this study, the reduced thickness of the OPyC layers was observed after SPS (Figure 6A1). This indicated that the oxidation of OPyC could occur during SPS ( at a vacuum degree of about $0.1 \mathrm{~Pa}$ ), leading to gas product of $\mathrm{CO} / \mathrm{CO}_{2}$. Besides, as reported in previous study, the reactions between $\mathrm{SiC}$ and $\mathrm{CO} / \mathrm{CO}_{2}$ could generate $\mathrm{SiO}(\mathrm{g})$ and $\mathrm{C}$ when the partial pressure of $\mathrm{CO} / \mathrm{CO}_{2}$ was low (see Figures 1 and 2, Ref.[27], active oxidation of $\mathrm{SiC}$ would occur when the $\mathrm{CO} / \mathrm{CO}_{2}$ pressure was lower than $\left.0.1 \mathrm{~Pa}\right)^{27}$. Therefore, the This article is protected by copyright. All rights reserved. 
formation of porous $\mathrm{SiC}$ might be caused by the trapped gas products from reactions at the

interface of the OPyC layer and the SiC matrix during SPS. The pores or gaps at the interface

between the TRISO particle and the SiC matrix would be detrimental to the heat transfer

from TRISO particle to SiC matrix. So a high vacuum degree of sintering system would be

required to control/eliminate the formation of the pores.

Figure 7 presents the line mapping of Raman spectra through the porous SiC from the

OPyC layer to $\mathrm{SiC}$ matrix. The peaks at $\sim 796 \mathrm{~cm}^{-1}$ corresponds to the TO band of $\beta-\mathrm{SiC}$ with second-order peaks between $1400 \mathrm{~cm}^{-1}$ and $1800 \mathrm{~cm}^{-1}$, while the two peaks at $\sim 1360 \mathrm{~cm}^{-1}$ and $\sim 1580 \mathrm{~cm}^{-1}$ are the $\mathrm{D}$ band and $\mathrm{G}$ band for amorphous carbon, respectively. It can be seen that the $\mathrm{SiC}$ matrix only presents the Raman peaks of $\mathrm{SiC}$, and the OPyC layer only shows the Raman peaks of amorphous carbon. However, both the Raman specta of SiC and amorphous carbon appeared in the region of porous $\mathrm{SiC}$. The presence of carbon in the porous $\mathrm{SiC}$ further confirmed the reactions between $\mathrm{SiC}$ and $\mathrm{CO} / \mathrm{CO}_{2}$ with the formation of $\mathrm{SiO}(\mathrm{g})$ and carbon. Besides, the intensity of the $\mathrm{D}$ band and $\mathrm{G}$ band in the porous $\mathrm{SiC}$ tended to increase when close to the OPyC layer. Thus, the progression of the reactions between $\mathrm{SiC}$ and $\mathrm{CO} / \mathrm{CO}_{2}$ was related to the diffusion of $\mathrm{CO} / \mathrm{CO}_{2}$ from the interface of the OPyC layer and This article is protected by copyright. All rights reserved. 
the $\mathrm{SiC}$ matrix. The possibility that the Raman spectra of carbon detected in the porous $\mathrm{SiC}$

was originated from the OPyC layer was excluded, because no Raman specta of carbon could

be detected from the SiC layer in TRISO particle, even when it was close to the OPyC layer.

TEM was employed to further characterize the microstructure at the interface between

TRISO particle with OPyC layer and $\mathrm{SiC}$ matrix, with the specimen cut across the interface

using FIB technique. FIB section was taken near the interfaces of TRISO particle with OPyC

layer and $\mathrm{SiC}$ matrix, as shown in Figure 8A. The interface between the OPyC layer and the

$\mathrm{SiC}$ matrix was seen to be rough and porous. Besides, many large pores were also observed

in the porous $\mathrm{SiC}$ zone (it should be noted that some big pores were caused by FIB milling).

Furthermore, the distribution of carbon in the porous $\mathrm{SiC}$ was also presented in the

bright-field TEM image with the energy-dispersive X-ray spectroscopy (EDS) mapping of C

and Si (Figure 8D). This is in agreement with the results of the Raman line mapping of

Figure 7. And both small and large size of carbon were involved, a range of $50 \mathrm{~nm}$ to 300

nm. For comparison, the characterization of the microstructure at the interface between

TRISO particle without OPyC layer and SiC matrix was also performed using TEM, as is

shown in Figure 9. The interface between the $\mathrm{SiC}$ layer and the $\mathrm{SiC}$ matrix clearly remains

This article is protected by copyright. All rights reserved. 
intact and keeps tight cohesion without apparent interface. The differences in the microstructure between the $\mathrm{SiC}$ layer and the $\mathrm{SiC}$ matrix can also be observed. The $\mathrm{SiC}$ grain size in the SiC matrix is smaller (range from $300 \mathrm{~nm}$ to $1 \mu \mathrm{m}$ ) than that in the $\mathrm{SiC}$ layer. Moreover, EDS mapping of $\mathrm{O}, \mathrm{Y}$ and $\mathrm{Al}$ indicates the segregation of the oxide additives at the triple points and grain boundaries in the $\mathrm{SiC}$ matrix (Figure 9D).

\subsection{The thermal effects on the microstructure of TRISO particle during SPS}

As was discussed above, the SPS process resulted in both the annihilation of the stacking faults (Figure 3) and the grain growth in $\mathrm{SiC}$ matrix compared with the starting $\mathrm{SiC}$ powder

(Figures 1 and 4). It is also worth noting that the thermal effects of the high fabrication temperature on the microstructure of TRISO particles, especially the PyC layers. Figure 10 shows Raman spectra for the PyC layers, which exhibit two relatively broad D band and G band. The band at $1600 \mathrm{~cm}^{-1}$ is an overlap of broadened $\mathrm{G}$ and $\mathrm{D}^{\prime}\left(1620 \mathrm{~cm}^{-1}\right)$ bands due to the highly disordered pyrolytic carbon ${ }^{28}$. The D band and D' represent the in-plane defects, while the $G$ band represents the ordered structure in the graphene planes ${ }^{13,29}$. The split of $G$ and D' bands could be observed after the SPS procedure at $1850{ }^{\circ} \mathrm{C}$, which indicates the thermal experience decreased the degree of disorder in the PyC layers ${ }^{30}$. Besides, the split of This article is protected by copyright. All rights reserved. 
the $G$ and $D^{\prime}$ bands became more significant with an increase of the dwelling time, suggesting more significant change in on the degree of disorder in the PyC layers during SPS.

According to previous studies, the Raman spectra of PyC layers can be deconvoluted into four peaks at about $1220 \mathrm{~cm}^{-1}$ (I band), $1335 \mathrm{~cm}^{-1}$ (D band), $1500 \mathrm{~cm}^{-1}$ (D" band) and $1600 \mathrm{~cm}^{-1}$ (G band) ${ }^{13}$. Then, the full width at half maximum (FWHM) of the D band and intensity ratio of the $\mathrm{D}$ " bands (i.e., the area ratio of the $1500 \mathrm{~cm}^{-1}$ peak to the sum of four peaks shown in Figure 11C) can be related to the degree of in-plane and out-of-plane disorder in PyC layers, respectively ${ }^{13,30,31}$. Figure 11 shows the FWHM of the D band and intensity ratio of the D" bands for the PyC layers, respectively. The inset (Figure 11C) shows the fitting of Raman spectra of PyC layers using four bands. For the OPyC layers, the FWHM of the $\mathrm{D}$ band decreased significantly from $\sim 110 \mathrm{~cm}^{-1}$ (as-deposited) to $\sim 50 \mathrm{~cm}^{-1}\left(1850{ }^{\circ} \mathrm{C}-10\right.$ $\min )$, and then to about $40 \mathrm{~cm}^{-1}\left(1850{ }^{\circ} \mathrm{C}-20 \mathrm{~min}\right)$. Similarly, the intensity ratio of the D" decreased from $\sim 0.35$ (as-deposited) to $\sim 0.09$ (1850 ${ }^{\circ} \mathrm{C}-10 \mathrm{~min}$ ), and then to $\sim 0.05$ (1850 $\left.{ }^{\circ} \mathrm{C}-20 \mathrm{~min}\right)$. Such changes indicate a decrease of both the in-plane disorder and the out-of-plane defects in the OPyC layers due to the thermal effects after SPS ${ }^{13}$. and the concentration of defects decreased obviously with an increase of dwelling time. The IPyC This article is protected by copyright. All rights reserved. 
layers showed similar trends as the OPyC layers. However, the buffer layers exhibited less changes, especially in term of the the intensity ratio of the D", which can attribute to the dominant defects in PyC layers of different densities according to the previous study ${ }^{13}$. It was reported that a combination of a high degree of in-plane and out-of plane defects prevail in high density PyC (e.g, IPyC and OPyC layers) ${ }^{13}$. However, in low density PyC (e.g, Buffer layer), the microstructure could remain almost unchanged after thermal treatment due to the dominant defects of five-membered rings ${ }^{13}$.

The thermal effects of the SPS procedure on the microstructure of the PyC layers could not only decrease the mechanical properties, but also degrade radiation resistance performance due to the reduction of disorders (e.g., anisotropic swelling) ${ }^{3,13}$. Therefore, the detrimental effect on TRISO particles due to the sintering process of FCM should be avoided by lowing the sintering temperature or shortening the dwelling time. Compared with the hot pressing sintering ${ }^{8,9}$, SPS technique can achieve high densification at a much shorter time (e.g., $10 \mathrm{~min}$ in this study), thus minimizing the microstructural degradation in TRISO particle induced by the thermal experience.

This article is protected by copyright. All rights reserved. 


\subsection{The thermal conductivity of $\mathrm{SiC}$ matrix and FCM}

Since one of the purposes of the FCM fuel was designed to transfer the fission heat originated from the embeded TRISO fuel particles, the thermal conductivity is an important parameter to predict the thermal efficiency of the fuel. Table 3 summarized the thermal diffusivity and thermal conductivity of the $\mathrm{SiC}$ ceramics (S1-S6) of various sintering conditions and the FCM pellets (F1-F3) with different TRISO particles. The thermal conductivity of the SiC ceramics increases slightly from $46.4 \mathrm{~W} / \mathrm{m} \mathrm{K}$ to $72.4 \mathrm{~W} / \mathrm{m} \mathrm{K}$ with an increase of relative density from $81 \%$ to $98 \%$ fabricated in different sintering conditions. It indicates that the porosity has a significant influence on the thermal conductivity of $\mathrm{SiC}$ matrix. The $\mathrm{SiC}$ matrix (S5) of near full density (98\% relative density) exhibited the highest thermal conductivity $(72.4 \mathrm{~W} / \mathrm{m} \mathrm{K})$ in spite of the large content of the low thermal condctivity oxide additives (10 wt.\%). The thermal conductivity of the $\mathrm{SiC}$ with 5 wt.\% oxide additives sintered at $1850{ }^{\circ} \mathrm{C}$ for $10 \mathrm{~min}(\mathrm{~S} 2)$ was $57.3 \mathrm{~W} / \mathrm{m} \mathrm{K}$. Because the sintering conditions of FCM pellets were similar to that of the sample S2, the thermal conductivity of the SiC matrix in FCM pellet was also assumed to be $57.3 \mathrm{~W} / \mathrm{m} \mathrm{K}$.

This article is protected by copyright. All rights reserved. 
With the presence of TRISO particles embedded in the $\mathrm{SiC}$ matrix, both the thermal diffusivity and the thermal conductivity of the FCM pellets reduced considerably as shown in

Table 3. The decrease in the thermal conductivity was caused by the reduction in the thermal diffusivity with the addition of TRISO particles, which consist of low thermally conductive zirconia kernels and coated layers ${ }^{32}$. Sample F1 is the FCM pellet with 24 vol.\% TRISO particles with OPyC layers, whoes thermal conductivity was measured to be $44.6 \mathrm{~W} / \mathrm{m} \mathrm{K}$. F2 is the FCM pellet that contained the same number of TRISO particles as F1 but without OPyC layers. The thermal conductivity of F1 was lower than that of F2 (50.3 W/m K), owing to the presence of the OPyC layers and the gaps/pores near the interface of the OPyC layers and SiC matrix in F1. F3 is the FCM pellet consists of 24 vol.\% TRISO particles without OPyC layers, meaning the number of the TRISO particles was more than that of F1. However, the thermal conductivity of $\mathrm{F} 3(47.7 \mathrm{~W} / \mathrm{m} \mathrm{K})$ was higher than that of $\mathrm{F} 1$. Therefore, for the same volume fraction of particles in FCM compact, the number of the TRISO particles without OPyC layers was much more than the TRISO particles with OPyC layers, which not only enabled higher the fuel kernel volume fraction, but also improved the thermal efficiency of the FCM with higher thermal conductivity.

This article is protected by copyright. All rights reserved. 


\subsection{The effective thermal conductivity of TRISO particle}

The effective thermal conductivity of whole TRISO particle is a critical parameter to determine the temperature distribution within a fuel compact. In this work, the Maxwell-Eucken equation was employed to analyze the effective thermal conductivity of the

TRISO particle, which is can be used to describe the thermal conductivity of isolated spherical inclusions dispersed in a continuous homogeneous matrix and presented by ${ }^{18}$ :

$$
k_{e f f}=k_{m}\left[\frac{k_{i}+2 k_{m}+2 v_{i}\left(k_{i}-k_{m}\right)}{k_{i}+2 k_{m}-v_{i}\left(k_{i}-k_{m}\right)}\right]
$$

where $v$ represents the volume fraction, $k$ is the thermal conductivity, $k_{\text {eff }}$ is the effective thermal condutivity of the composite and the subscripts $m$ and $i$ refer to the matrix and inclusions, respectively. Assuming the FCM is a composite, the effective thermal conductivity of TRISO particles was calculated to be $14.4 \mathrm{~W} / \mathrm{m} \mathrm{K}$ according to Equation (1), using the thermal conductivity of the SiC matrix, FCM pellet and the volume fraction of TRISO particles (Table 3). The value obtained in this study is slightly higher than that presented in a previous study $(12.01 \mathrm{~W} / \mathrm{mK})^{9}$, which might come from differences in the microstructure of both $\mathrm{SiC}$ matrix and TRISO particles after the fabrication of FCM pellets. 
Furthermore, the effective thermal conductivity of TRISO particle without OPyC layer was

calculated to be $\sim 25.2 \mathrm{~W} / \mathrm{m} \mathrm{K}$, which was much higher than that of the TRISO particle with

OPyC layer. The difference can attribute to the presence of the OPyC layer with the low thermal conductivity. Besides, the thermal resistence at the gaps between the OPyC layer and the $\mathrm{SiC}$ matrix, together with the porous $\mathrm{SiC}$ formed near the OPyC layer would also underestimate the effective thermal conductivity of TRISO particle.

Table 4 summarizes the basic physical parameters of the SiC matrix and TRISO particle, including the theoretical heat capacity ${ }^{33}$ and reported thermal conductivities of the individual layers in TRISO particle ${ }^{32}$. Based on the parameters in Table 4, the way heat flows through the matrix in the vicinity of a single TRISO particle within an external temperature gradient could be evaluated, as shown in Figure 12. Two cases have been considered. One was for the TRISO particle with the OPyC layer and the other was for TRISO particle without OPyC. Both the red arrow and grey streamline refer to the heat flux. Although the heat can flow through TRISO particle, most of the heat flows around the outside of TRISO particle (red arrows in Figure 12), due to the low thermally conductive TRISO particle. When assessing heat flow through a TRISO particle, regions of high heat flux lie on the SiC layer in TRISO This article is protected by copyright. All rights reserved. 
particle as the heat flow lines become squeezed on the passage through the SiC layer (grey streamlines in Figure 12). That is, the thermal conductivity of the $\mathrm{SiC}$ layer plays a dominant role on the effective thermal conductivity of TRISO particle. However, the presence of the OPyC layer with lower thermal conductivity hindered the way heat flows through the SiC layer. Besides, for the FCM pellets contained TRISO particles with OPyC layers, the gaps at the interface and the porous $\mathrm{SiC}$ formed near the OPyC layer would further resist the way heat flows through the $\mathrm{SiC}$ layer. Therefore, it's reasonable that the effective thermal conductivity of TRISO particle without OPyC layer was higher than that of the TRISO particle with OPyC layer.

Generally, for a composite material with multilayered structure, the calculation of effectvie thermal conductivity was based on the heat flux direction predicted in the model, such as series and parallel models that are in extreme cases ${ }^{17}$. However, the Maxwell-Eucken model used in this study assumed an external temperature gradient, which is different from the service condition, i.e., the heat conduction from fuel-kernels to $\mathrm{SiC}$ matrix. Therefore, the calculated effective thermal conductivity for TRISO particle or FCM might not reflect the real effective thermal conductivity of TRISO particle or FCM in nuclear reactor. This article is protected by copyright. All rights reserved. 
Nonetheless, the FCM pellet using TRISO particles without OPyC layers would exhibit a

higher thermal conducutivity.

\section{Conclusions}

To achieve a high-density SiC matrix with low amount of oxide additives and intact TRISO

particles embedded, the fabrication of FCM pellets were performed at $1850{ }^{\circ} \mathrm{C}$ with 5 wt.\%

oxide additives for $10 \mathrm{~min}$ of dwelling time under $15 \mathrm{MPa}$ of pressure using SPS technique.

The high temperature fabrication of SPS procedure resulted in significant decrease of both

the in-plane disorder and the out-of-plane defects in the PyC layers with an increase of

dwelling time.

Thermal conductivity of the FCM pellet was determined using laser flash technique. The

thermal conductivity of the FCM pellet with 24 vol.\% TRISO particles embedded was

measured to be $44.6 \mathrm{~W} / \mathrm{m} \mathrm{K}$. In contrast, the thermal conductivity of the FCM pellets that

consist of the same number and the same volume fraction of TRISO particles without OPyC

layers was $50.3 \mathrm{~W} / \mathrm{m} \mathrm{K}$ and $47.7 \mathrm{~W} / \mathrm{m} \mathrm{K}$, respectively. Therefore, the FCM pellets with

TRISO particles without OPyC layers could improve the thermal conductivity of the FCM,

This article is protected by copyright. All rights reserved. 
owing to the interface between the $\mathrm{SiC}$ matrix and the $\mathrm{SiC}$ layer exhibited good contact

without significant voids or evidence of debonding.

The effective thermal conductivity of TRISO particle was analyzed using

Maxwell-Eucken model. The effective thermal conductivity of TRISO particle with OPyC

layer was calculated as $14.4 \mathrm{~W} / \mathrm{m} \mathrm{K}$, while $25.2 \mathrm{~W} / \mathrm{m} \mathrm{K}$ for TRISO particle without OPyC

layer. The way heat flows through the matrix in the vicinity of a single particle within an

external temperature gradient was also simulated, suggesting the $\mathrm{SiC}$ layer plays a dominant

role on the effective particle conductivity. Both the presence of the OPyC layers and the

pores or gaps near the $\mathrm{OPyC}$ layer/SiC matrix interface formed during sintering process

hindered the heat flows through the SiC layer and resulted in a lower thermal conductivity.

\section{Acknowledgments}

This research was supported by International Science \& Technology Cooperation Program of

China (No. 2016YFE0100700) and the National Natural Science Foundation of China

(No.51472157, 51402058).

This article is protected by copyright. All rights reserved. 


\section{References}

1. Snead LL, Nozawa T, Katoh Y, Byun TS, Kondo S, and Petti DA. Handbook of SiC properties for fuel performance modeling. J Nucl Mater. 2007;371:329-377.

2. Powers JJ and Wirth BD. A review of TRISO fuel performance models. J Nucl Mater. 2010;405:74-82.

3. Bonal JP, Kohyama A, van der Laan J, and Snead LL. Graphite, Ceramics, and Ceramic Composites for High-Temperature Nuclear Power Systems. MRS Bull. 2009;34:28-34.

4. Snead LL, Terrani KA, Venneri F, Kim Y, Tulenko JE, Forsberg CW, Peterson PF, and Lahoda EJ. Fully Ceramic Microencapsulated Fuels: A Transformational Technology for Present and Next Generation Reactors-Properties and Fabrication of FCM Fuel. Trans Am Nucl Soc. 2011;104:668-670.

5. Terrani KA, Kiggans JO, Katoh Y, Shimoda K, Montgomery FC, Armstrong BL, Parish CM, Hinoki T, Hunn JD, and Snead LL. Fabrication and characterization of fully ceramic microencapsulated fuels. J Nucl Mater. 2012;426:268-276.

This article is protected by copyright. All rights reserved. 
6. Terrani KA, Snead LL, and Gehin JC. Microencapsulated fuel technology for commercial light water and advanced reactor application. J Nucl Mater. 2012;427:209-224.

7. Snead LL, Terrani KA, Katoh Y, Silva C, Leonard KJ, and Perez-Bergquist AG. Stability of SiC-matrix microencapsulated fuel constituents at relevant LWR conditions. $J$ Nucl Mater. 2014;448:389-398.

8. Terrani KA, Kiggans JO, Silva CM, Shih C, Katoh Y, and Snead LL. Progress on matrix $\mathrm{SiC}$ processing and properties for fully ceramic microencapsulated fuel form. $J \mathrm{Nucl}$ Mater. 2015;457:9-17.

9. Lee HG, Kim D, Lee SJ, Park JY, and Kim WJ. Thermal conductivity analysis of SiC ceramics and fully ceramic microencapsulated fuel composites. Nucl Eng Des. 2017;311:9-15.

10. Besmann TM, Ferber MK, Lin HT, and Collin BP. Fission product release and survivability of UN-kernel LWR TRISO fuel. J Nucl Mater. 2014;448:412-419.

This article is protected by copyright. All rights reserved. 
11. Chun JH, Lim SW, Chung BD, and Lee WJ. Safety evaluation of accident-tolerant FCM fueled core with SiC-coated zircalloy cladding for design-basis-accidents and beyond DBAs. Nucl Eng Des. 2015;289:287-295.

12. Lomello F, Bonnefont G, Leconte Y, Herlin-Boime N, and Fantozzi G. Processing of nano-SiC ceramics: Densification by SPS and mechanical characterization. J Eur Ceram Soc. 2012;32:633-641.

13. Zhang H, López-Honorato E, and Xiao P. Fluidized bed chemical vapor deposition of pyrolytic carbon-III. Relationship between microstructure and mechanical properties. Carbon. 2015;91:346-357.

14. Zhang H, Lopez-Honorato E, and Xiao P. Effect of Thermal Treatment on Microstructure and Fracture Strength of SiC Coatings. J Am Ceram Soc. 2013;96:1610-1616.

15. Munir ZA, Anselmi-Tamburini U, and Ohyanagi M. The effect of electric field and pressure on the synthesis and consolidation of materials: A review of the spark plasma sintering method. J Mater Sci. 2006;41:763-777.

This article is protected by copyright. All rights reserved. 
16. Guillard F, Allemand A, Lulewicz JD, and Galy J. Densification of SiC by SPS-effects of time, temperature and pressure. J Eur Ceram Soc. 2007;27:2725-2728.

17. Lee Y, Cho B, and Cho NZ. Steady- and Transient-State Analyses of Fully Ceramic Microencapsulated Fuel with Randomly Dispersed Tristructural Isotropic Particles via Two-Temperature Homogenized Model-I: Theory and Method. Nucl Eng Technol. 2016;48:650-659.

18. Tessier-Doyen N, Grenier X, Huger M, Smith DS, Fournier D, and Roger JP. Thermal conductivity of alumina inclusion/glass matrix composite materials: local and macroscopic scales. J Eur Ceram Soc. 2007;27:2635-2640.

19. Borrero-López O, Ortiz AL, Guiberteau F, and Padture NP. Sliding-Wear-Resistant Liquid-Phase-Sintered SiC Processed Using $\alpha$-SiC Starting Powders, J Am Ceram Soc. 2007; 90: 541-545.

20. Park JS, Kohyama A, Hinoki T, Shimoda K, and Park YH. Efforts on large scale production of NITE-SiC/SiC composites. J Nucl Mater. 2007;367:719-724.

This article is protected by copyright. All rights reserved. 
21. Lanfant B, Leconte Y, Bonnefont G, Garnier V, Jorand Y, Le Gallet S, Pinault M, Herlin-Boime N, Bernard F, and Fantozzi G. Effects of carbon and oxygen on the spark plasma sintering additive-free densification and on the mechanical properties of nanostructured SiC ceramics. J Eur Ceram Soc. 2015;35:3369-3379.

22. Pujar VV and Cawley JD. Computer simulations of diffraction effects due to stacking faults in beta-SiC: II, experimental verification. J Am Ceram Soc. 2001;84:2645-2651.

23. Ciudad E, Sanchez-Gonzalez E, Borrero-Lopez O, Guiberteau F, Nygren M, and Ortiz AL. Sliding-wear resistance of ultrafine-grained $\mathrm{SiC}$ densified by spark plasma sintering with $3 \mathrm{Y}_{2} \mathrm{O}_{3}+5 \mathrm{Al}_{2} \mathrm{O}_{3}$ or $\mathrm{Y}_{3} \mathrm{Al}_{5} \mathrm{O}_{12}$ additives. Scripta Mater. 2013;69:598-601.

24. Lorrette C, Réau A, and Briottet L. Mechanical properties of nanostructured silicon carbide consolidated by spark plasma sintering. J Eur Ceram Soc. 2013;33:147-156.

25. Piat R and Schnack E. Modeling the effect of microstructure on the coefficients of thermal expansion of pyrolytic carbon. Carbon. 2003;41:2162-2165.

26. Li Z and Bradt RC. Thermal expansion of the cubic (3C) polytype of SiC. J Mater Sci. 1986;21:4366-4368.

This article is protected by copyright. All rights reserved. 
27. Wang GX, Lu GQ, Pei BY, and Yu AB. Oxidation mechanism of $\mathrm{Si}_{3} \mathrm{~N}_{4}$-bonded $\mathrm{SiC}$ ceramics by CO, $\mathrm{CO}_{2}$ and steam. J Mater Sci. 1998;33:1309-1317.

28. Ferrari AC. Raman spectroscopy of graphene and graphite: Disorder, electron-phonon coupling, doping and nonadiabatic effects. Solid State Commun. 2007;143:47-57.

29. Lopez-Honorato E, Meadows PJ, and Xiao P. Fluidized bed chemical vapor deposition of pyrolytic carbon-I. Effect of deposition conditions on microstructure. Carbon. $2009 ; 47: 396-410$.

30. Vallerot JM, Bourrat X, Mouchon A, and Chollon G. Quantitative structural and textural assessment of laminar pyrocarbons through Raman spectroscopy, electron diffraction and few other techniques. Carbon. 2006;44:1833-1844.

31. Rouzaud JN and Oberlin A. Carbon films: structure and microtexture (optical and electron microscopy, Raman spectroscopy). Thin Solid Films. 1983;105:75-96.

32. López-Honorato E, Chiritescu C, Xiao P, Cahill DG, Marsh G, and Abram T. Thermal conductivity mapping of pyrolytic carbon and silicon carbide coatings on simulated fuel particles by time-domain thermoreflectance. J Nucl Mater. 2008;378:35-39. This article is protected by copyright. All rights reserved. 
33. Domalski ES and Hearing ED. Heat capacities and entropies of organic compounds in the condensed phase volume III. J Phys Chem Ref Data. 1997;26:1501-1505.

\section{Figure captions}

Figure 1 Transmission electron microscope (TEM) images of the starting SiC nanopowder.

Figure 2 XPS spectra of the starting SiC powder and the pure SPS SiC sample.

Figure 3 XRD patterns of the starting $\mathrm{SiC}$ powder, the mixed powder with $5 \mathrm{wt} . \%$ sintering additives and SiC matrix after SPS.

Figure 4 SEM images (A-F) correspond to the microstructure of SiC ceramics (S1-S6) using SPS processing at $1850{ }^{\circ} \mathrm{C}$ with various sintering condtions.

Figure 5 FCM samples with (A) TRISO particles with OPyC layers and (B) TRISO particles without OPyC layers embedded in SiC matrix.

This article is protected by copyright. All rights reserved. 
Figure 6 The interface between (A) the TRISO particle with OPyC layer and (B) TRISO

particle without $\mathrm{OPyC}$ layer and the $\mathrm{SiC}$ matrix, with the higher magnification image of $\mathrm{A} 2$

and $\mathrm{B} 2$ showing the porous $\mathrm{SiC}$ and the interface, respectively.

Figure 7 The line mapping of Raman spectra through the porous $\mathrm{SiC}$ from the $\mathrm{OPyC}$ layer to

$\mathrm{SiC}$ matrix.

Figure 8 TEM images of the microstructure near the interface between TRISO particle with

OPyC layer and $\mathrm{SiC}$ matrix, with EDS mapping for $\mathrm{C}$ in porous $\mathrm{SiC}$.

Figure 9 TEM images of the microstructure near the interface between TRISO particle

without $\mathrm{OPyC}$ layer and $\mathrm{SiC}$ matrix, with $\mathrm{EDS}$ mapping for $\mathrm{O}, \mathrm{Al}$ and $\mathrm{Y}$ in the $\mathrm{SiC}$ matrix.

Figure 10 Raman spectra for (A) the OPyC layer, (B) the IPyC layer and (C) the buffer layer

for different dwelling time for SPS.

Figure 11 (A) the full width at half maximum (FWHM) of the D band and (B) the intensity

ratio of the D" bands, i.e., the area ratio of the $1500 \mathrm{~cm}^{-1}$ peak to the sum of four peaks at about $1220 \mathrm{~cm}^{-1}$ (I band), $1335 \mathrm{~cm}^{-1}$ (D band), $1500 \mathrm{~cm}^{-1}$ (D" band) and $1600 \mathrm{~cm}^{-1}$ (G band)

shown in the inset $(\mathrm{C})$.

This article is protected by copyright. All rights reserved. 
Figure 12 The model of the way heat flows through the matrix in the vicinity of a single (A)

TRISO particle with OPyC layer and (B) TRISO particle without OPyC layer within an

external temperature gradient.

\section{Table captions}

Table 1 The SPS conditions for the fabrication of SiC matrix (S1-S6) at $1850{ }^{\circ} \mathrm{C}$.

Table 2 Density (relative density * in parenthesis) and mechanical property of the SiC matrix

(S1-S6) fabricated with various sintering conditions.

Table 3 Specific heat capacity $\left(c_{p}\right)$, thermal diffusivity $(\alpha)$ and thermal conductivity $(k)$ of the

SiC matrix (S1-S6) and the FCM pellet (F1-F3) with different volume fraction $\left(v_{i}\right)$ of TRISO

particles.

* The relative density of sintered materials was calculated using the theoretical density of the $\mathrm{SiC}$ matrix according to the ratio of mixture, using theoretical density for YAG and $\mathrm{SiC}$ of $4.54 \mathrm{~g} / \mathrm{cm}^{3}$ and $3.21 \mathrm{~g} / \mathrm{cm}^{3}$, respectively.

This article is protected by copyright. All rights reserved. 
Table 4 A summary of diameter, density, heat capacity $\left(c_{p}\right)$ and thermal conductivity $(k)$ for the heat flux model through the matrix in the vicinity of a single TRISO particle.

Table 1 The SPS conditions for the fabrication of SiC matrix (S1-S6) at $1850{ }^{\circ} \mathrm{C}$

\begin{tabular}{llll}
\hline Sample & Sintering pressure (MPa) & Oxide additives (wt.\%) & Dwelling time (min) \\
\hline S1 & 10 & 5 & \\
S2 & 15 & & 10 \\
S3 & 20 & 2 & \\
S4 & & 10 & 20 \\
S5 & 15 & 5 & \\
S6 & & 5 & \\
\hline
\end{tabular}

This article is protected by copyright. All rights reserved. 
Table 2 Density (relative density ${ }^{\dagger}$ in parenthesis) and mechanical property of the $\mathrm{SiC}$ matrix (S1-S6) fabricated with various sintering conditions

\begin{tabular}{llll}
\hline Sample & Density $\left(\mathrm{g} / \mathrm{cm}^{3}\right)$ & Hardness $(\mathrm{GPa})$ & Young's modulus $(\mathrm{GPa})$ \\
\hline $\mathrm{S} 1$ & $2.70(83 \%)$ & 15.7 & 271 \\
S2 & $2.97(91 \%)$ & 21.3 & 313 \\
S3 & $3.14(96 \%)$ & 25.6 & 380 \\
S4 & $2.63(81 \%)$ & 14 & 264 \\
S5 & $3.24(98 \%)$ & 23.3 & 356 \\
S6 & $3.01(92 \%)$ & 19.2 & 318 \\
\hline
\end{tabular}

${ }^{\dagger}$ The relative density of sintered materials was calculated using the theoretical density of the $\mathrm{SiC}$ matrix according to the ratio of mixture, using theoretical density for YAG and SiC of $4.54 \mathrm{~g} / \mathrm{cm}^{3}$ and $3.21 \mathrm{~g} / \mathrm{cm}^{3}$, respectively.

This article is protected by copyright. All rights reserved. 
Table 3 Specific heat capacity $\left(c_{p}\right)$, thermal diffusivity $(\alpha)$ and thermal conductivity $(k)$ of the SiC matrix (S1-S6) and the FCM pellet (F1-F3) with different volume fraction $\left(v_{i}\right)$ of TRISO particles

\begin{tabular}{|c|c|c|c|c|}
\hline Sample & $v_{i}($ vol. \%) & $c_{p}\left(\mathrm{~J} / \mathrm{g}^{\circ} \mathrm{C}\right)$ & $\alpha\left(\mathrm{mm}^{2} / \mathrm{s}\right)$ & $k(\mathrm{~W} / \mathrm{mK})$ \\
\hline S1 & & 0.675 & 26.66 & 49.0 \\
\hline $\mathrm{S} 2$ & & 0.681 & 28.32 & 57.3 \\
\hline S3 & & 0.685 & 30.75 & 65.3 \\
\hline & 0 & & & \\
\hline S4 & & 0.667 & 25.89 & 46.4 \\
\hline S5 & & 0.673 & 32.81 & 72.4 \\
\hline S6 & & 0.681 & 29.04 & 59.5 \\
\hline $\mathrm{F} 1$ & 24 & 0.685 & 22.44 & 44.6 \\
\hline $\mathrm{F} 2$ & 20 & 0.671 & 25.48 & 50.3 \\
\hline F3 & 24 & 0.675 & 23.93 & 47.7 \\
\hline
\end{tabular}

This article is protected by copyright. All rights reserved. 
Table 4 A summary of diameter, density, heat capacity $\left(c_{p}\right)$ and thermal conductivity $(k)$ for the heat flux model through the matrix in the vicinity of a single TRISO particle

\begin{tabular}{lllll}
\hline Materials & Diameter $(\mu \mathrm{m})$ & Density $\left(\mathrm{g} / \mathrm{cm}^{3}\right)$ & $c_{p}\left(\mathrm{~J} / \mathrm{g}^{\circ} \mathrm{C}\right)$ & $k(\mathrm{~W} / \mathrm{mK})$ \\
\hline $\mathrm{ZrO}_{2}$ kernel & 510 & 5.6 & $0.460^{32}$ & 3 \\
Buffer & 700 & 0.88 & $0.771^{32}$ & $5.7^{29}$ \\
$\mathrm{IPyC}$ & 780 & 1.93 & $0.771^{32}$ & $13.5^{29}$ \\
$\mathrm{SiC}$ & 850 & 3.19 & $0.661^{32}$ & $168^{29}$ \\
$\mathrm{OPyC}$ & 930 & 1.96 & $0.771^{32}$ & $13.5^{29}$ \\
$\mathrm{SiC}$ matrix & - & 2.97 & 0.681 & 57.3 \\
\hline
\end{tabular}

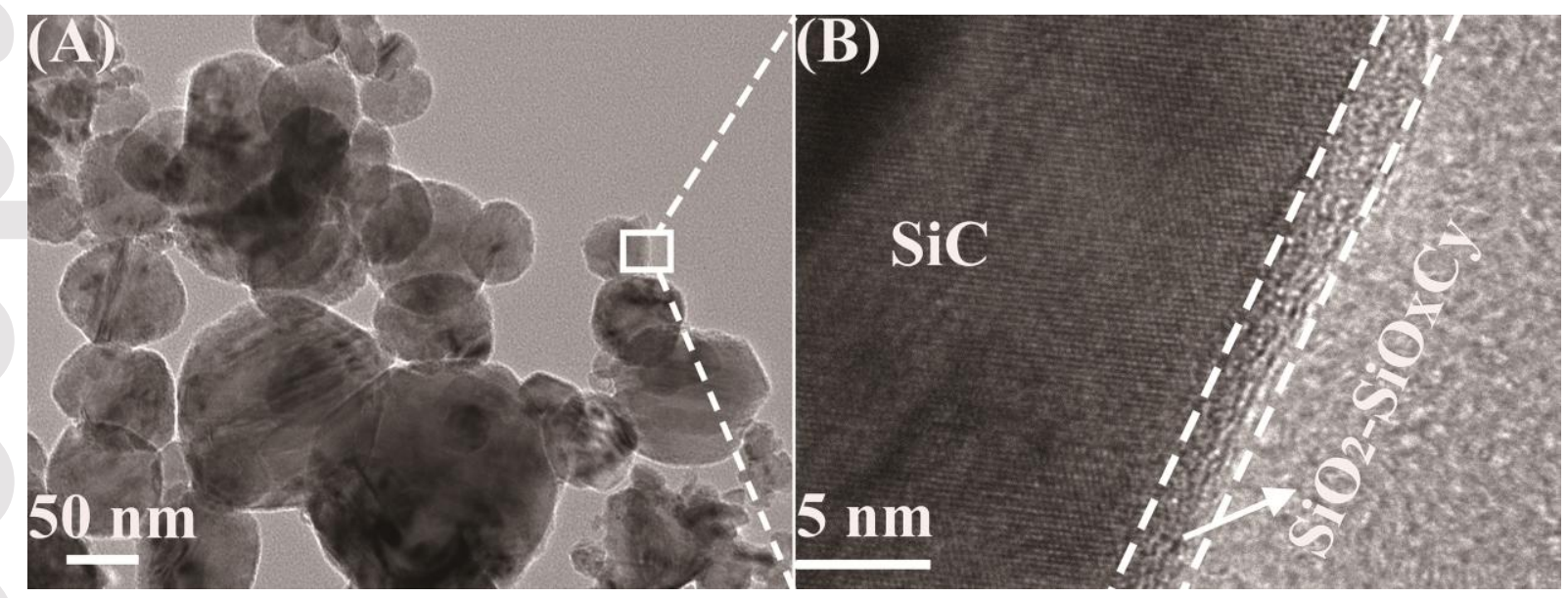

This article is protected by copyright. All rights reserved. 


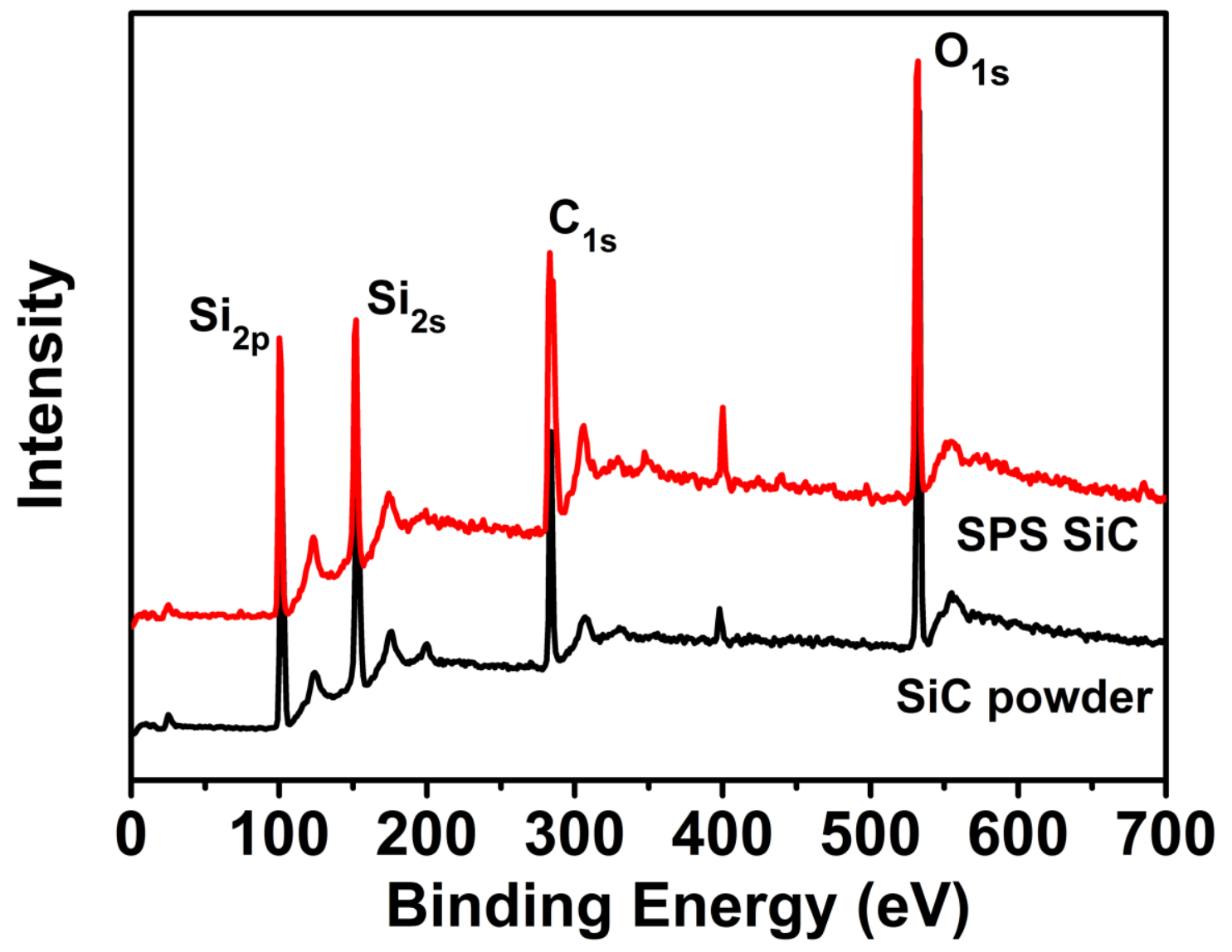

This article is protected by copyright. All rights reserved. 


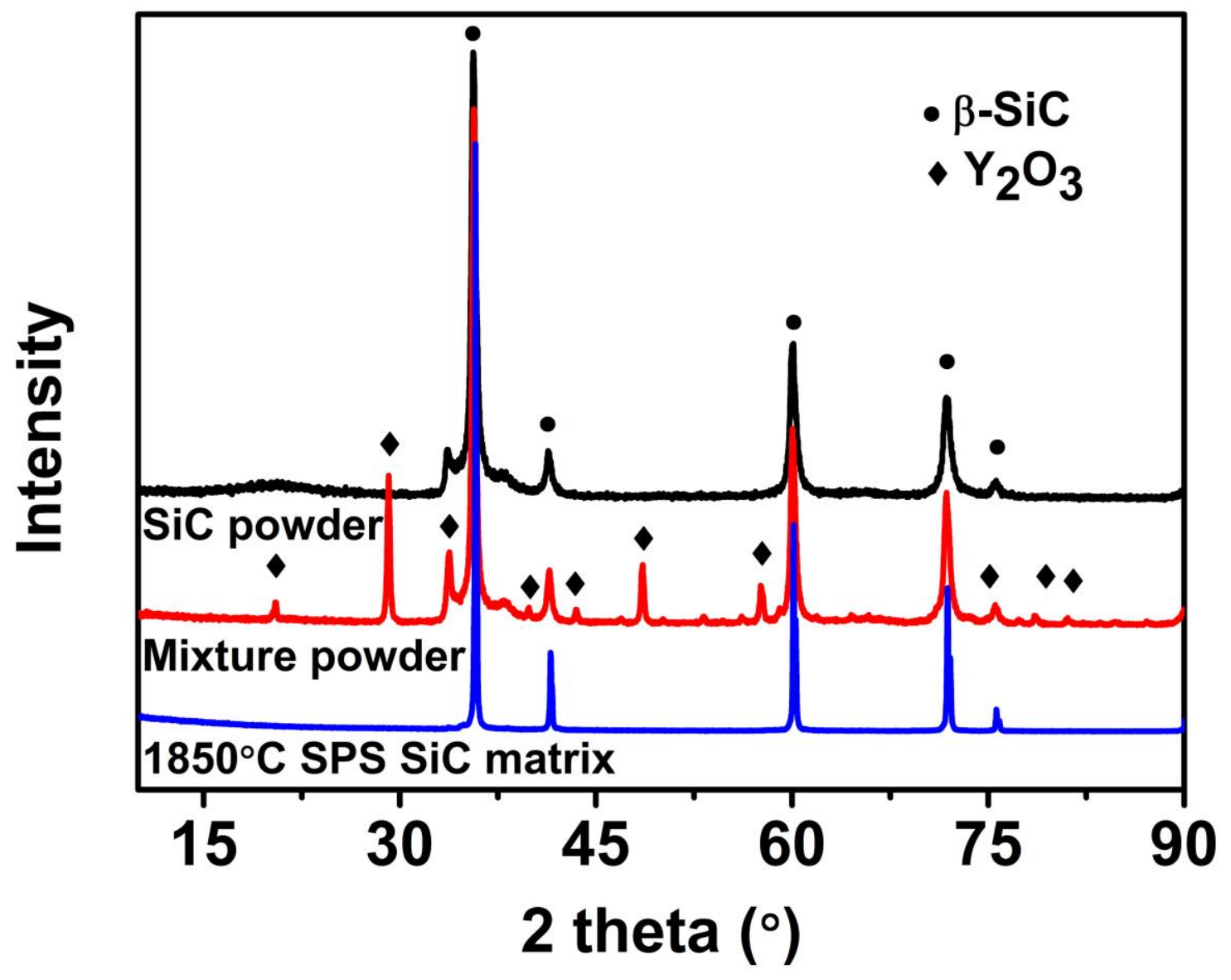

This article is protected by copyright. All rights reserved. 


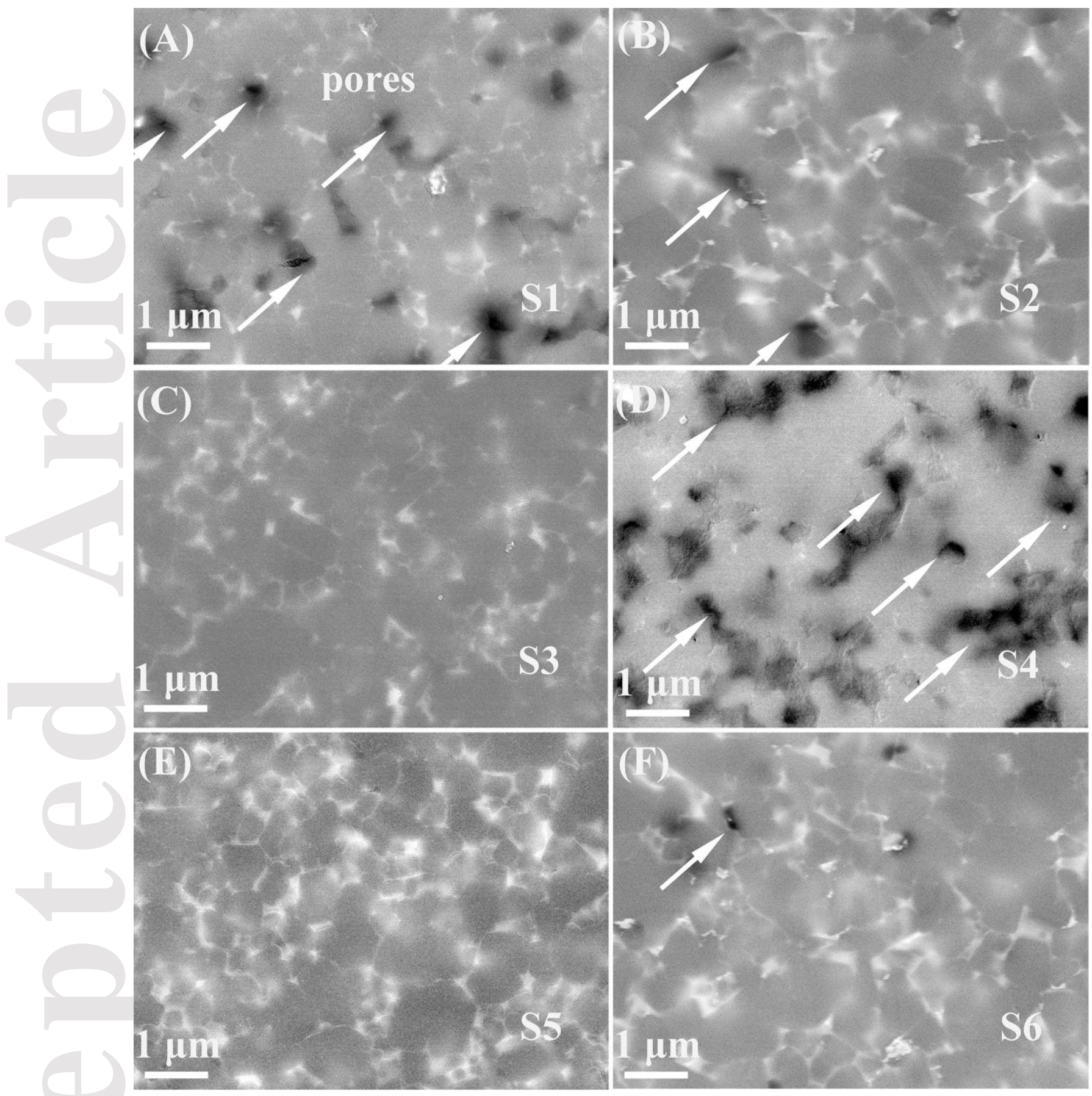

This article is protected by copyright. All rights reserved. 


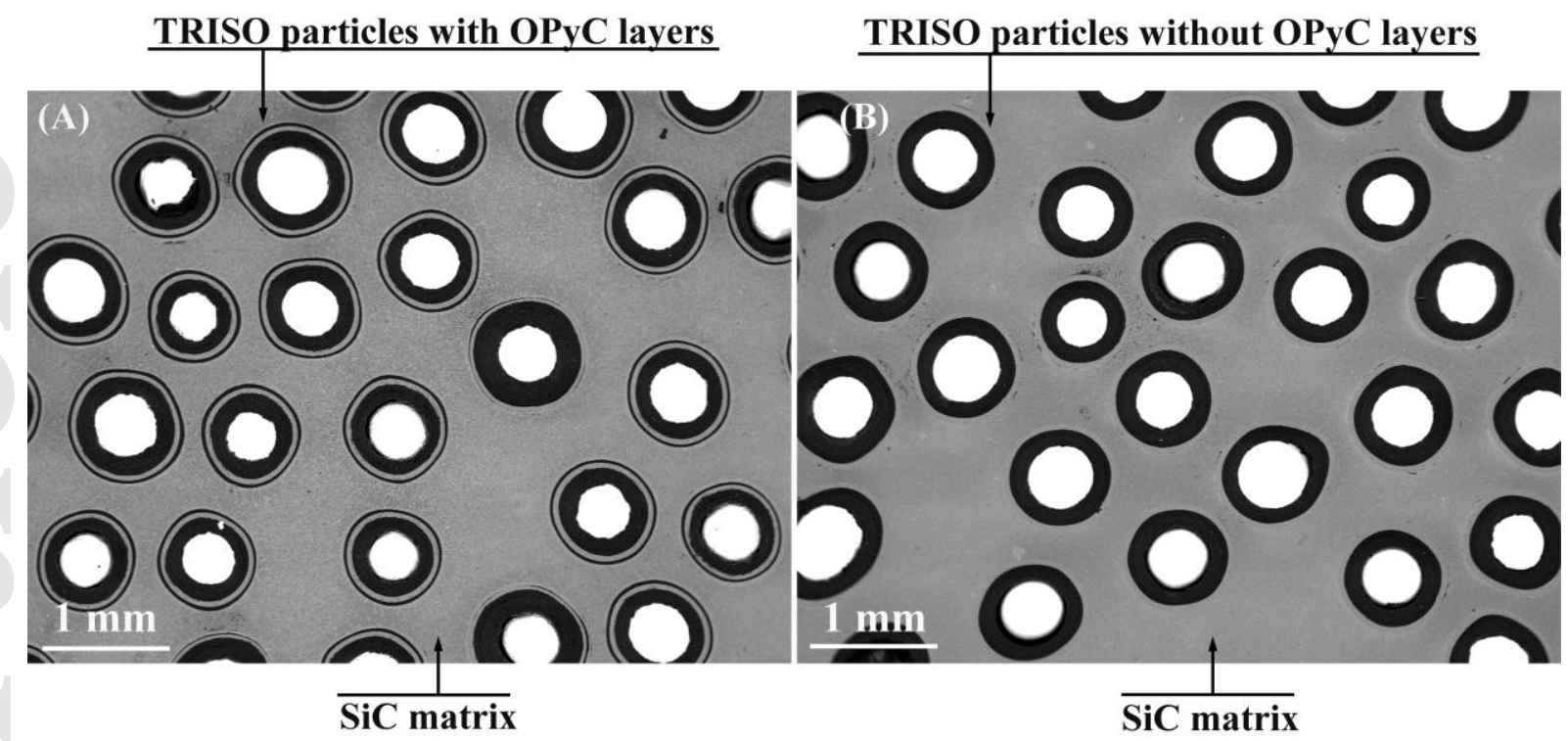

This article is protected by copyright. All rights reserved. 


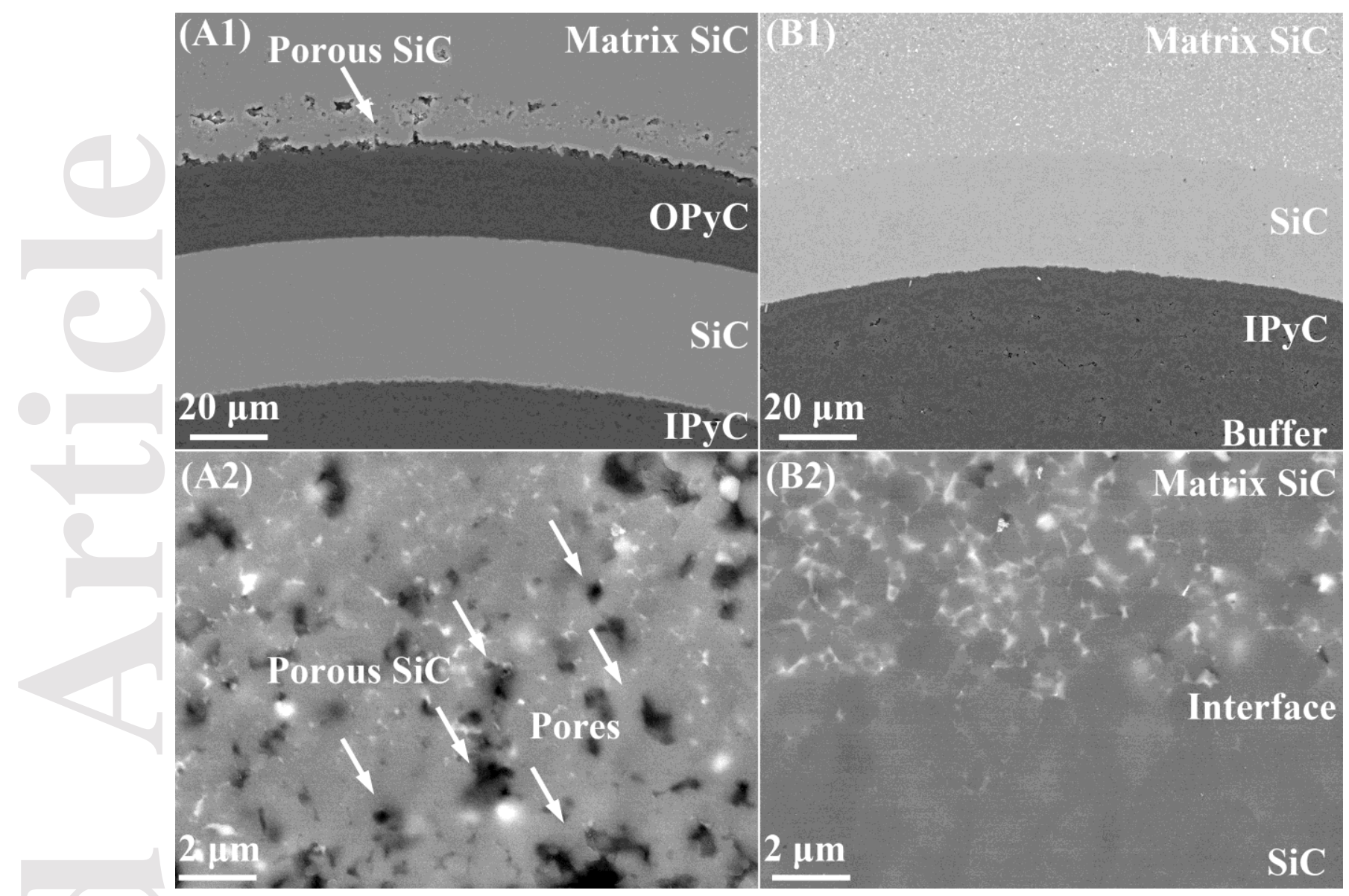

This article is protected by copyright. All rights reserved. 


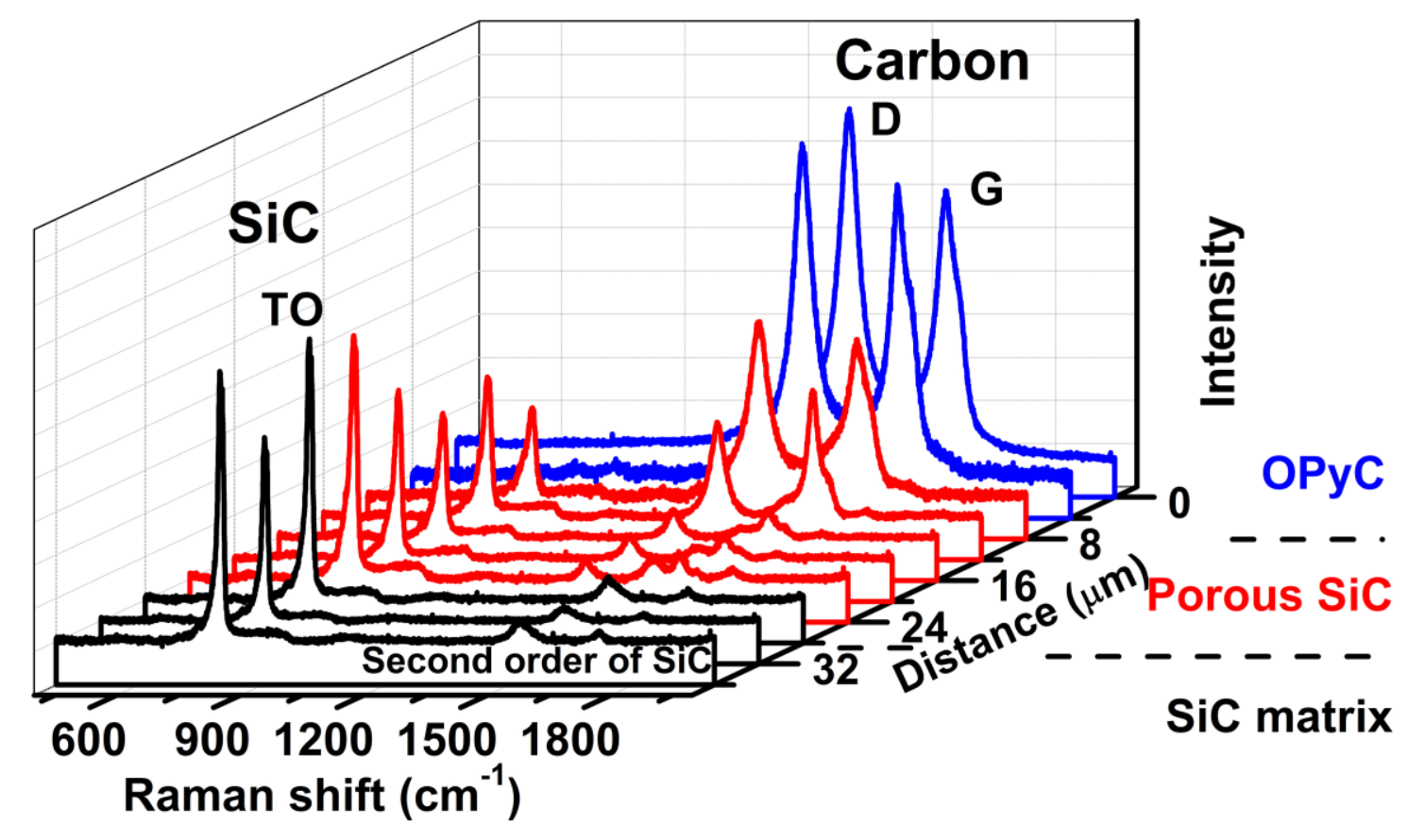

This article is protected by copyright. All rights reserved. 

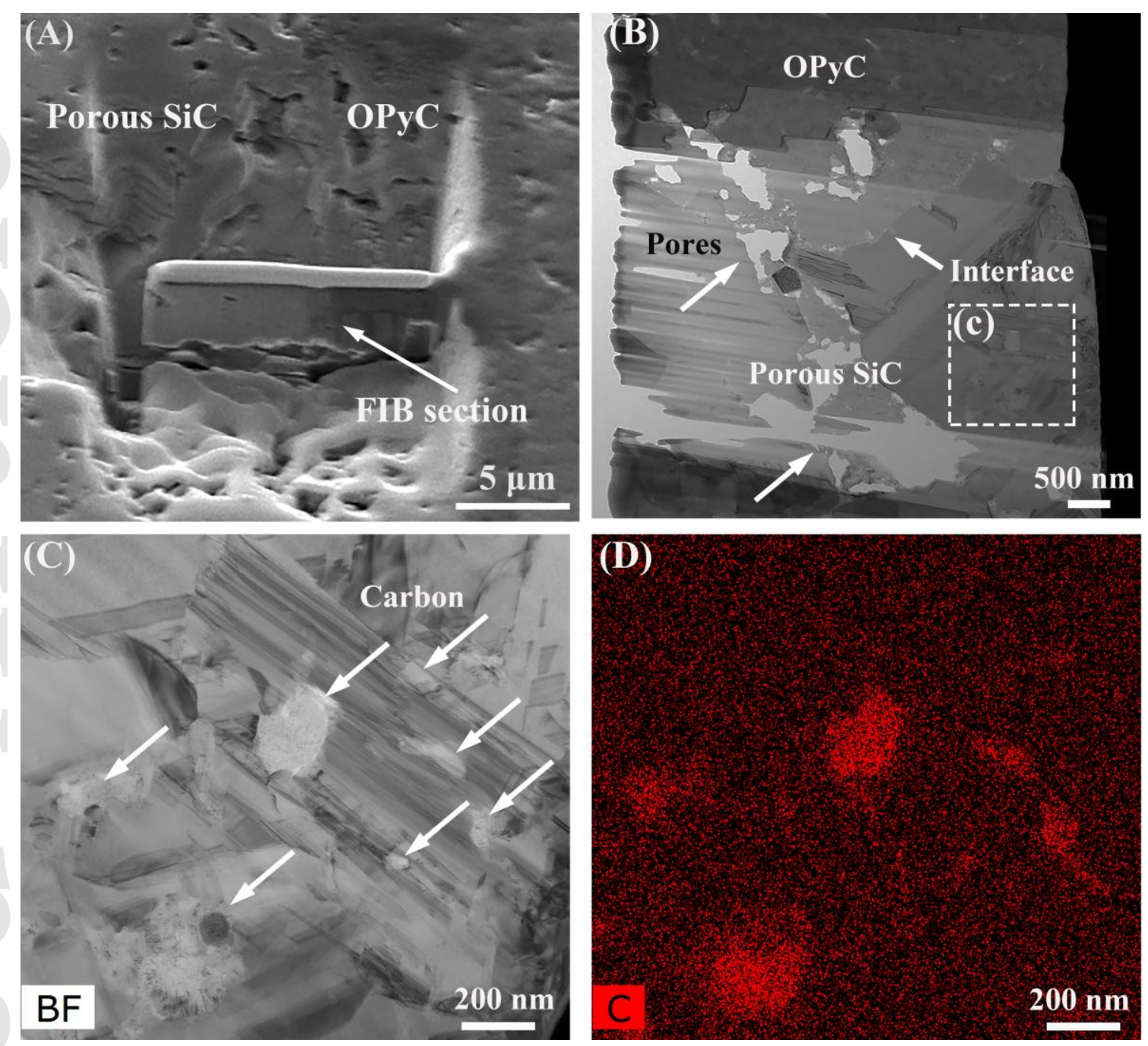

This article is protected by copyright. All rights reserved. 

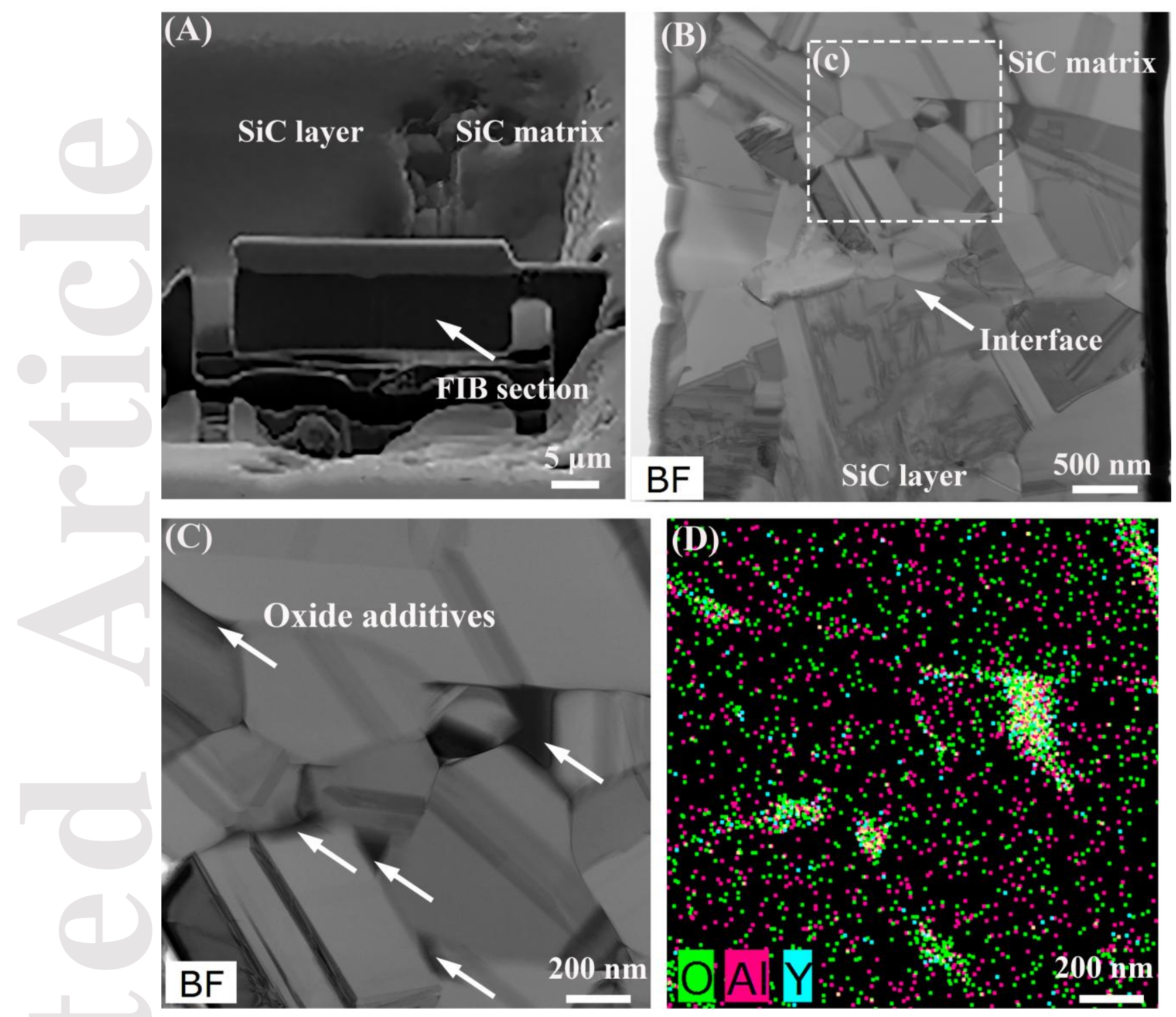

This article is protected by copyright. All rights reserved. 

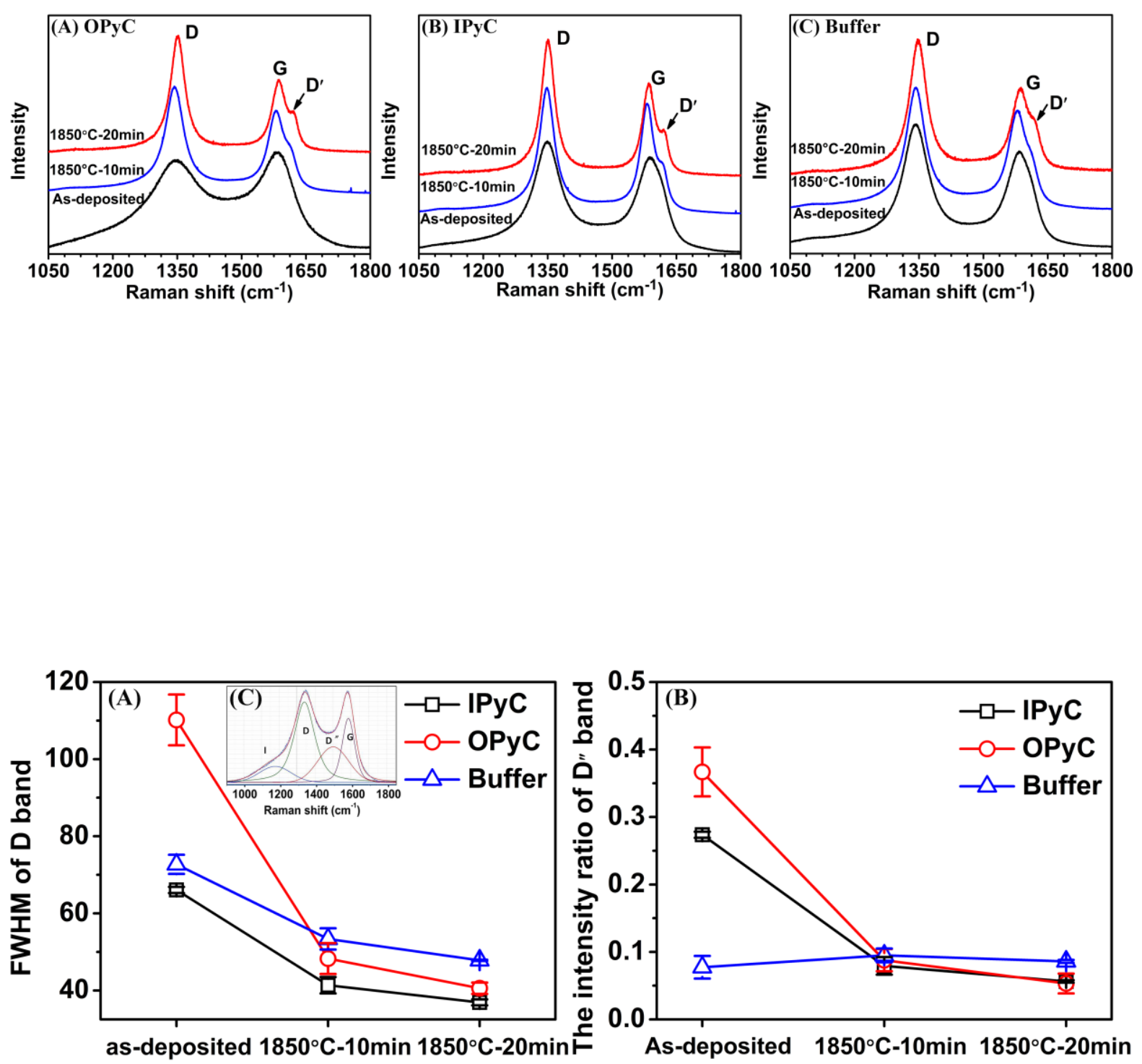

This article is protected by copyright. All rights reserved. 
(A) TRISO particle

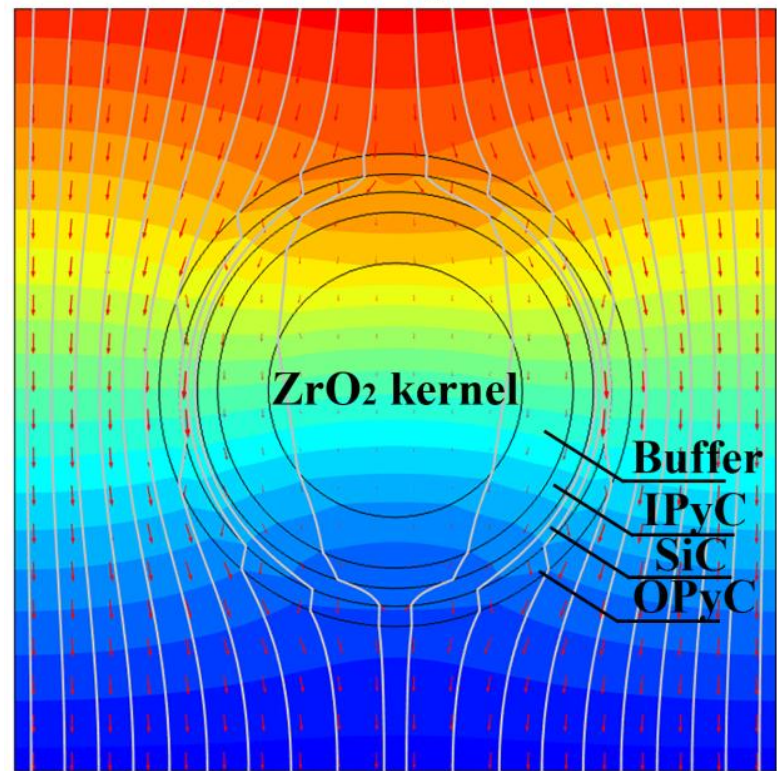

(B) TRISO particle without OPyC

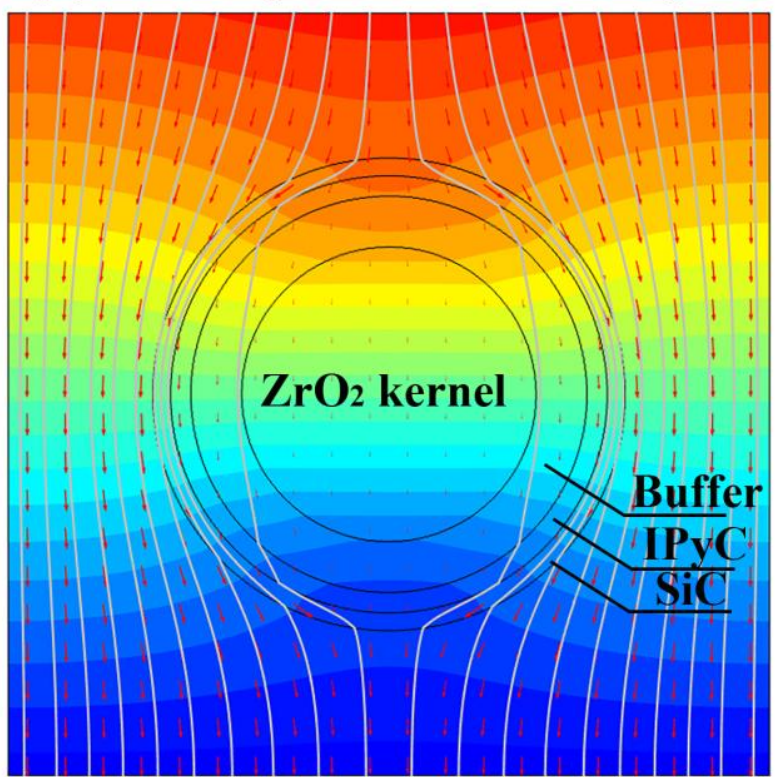

Both the red arrow and grey streamline refer to the heat flux.

This article is protected by copyright. All rights reserved. 